\title{
ANAlysis Of Drought In EAstern Part OF BANGLADESH
}

\author{
Keka Israt A. ${ }^{1}$, Matin I. ${ }^{2}$, Rahman M. ${ }^{3}$ and Banu D.A. ${ }^{4}$ \\ ${ }^{1,3,4}$ Department of Physics, University of Rajshahi \\ ${ }^{2}$ Department of Civil Engineering, RUET
}

E-mail: ishrat_keka@yahoo.com; imatinbd@yahoo.com; mrphy.ru@gmail.com; dab_dexa@yahoo.com

\begin{abstract}
Analysis of drought is very important for the irrigation purpose of a country. In this work analysis of drought in the eastern part of Bangladesh has been studied. Yearly meteorological drought has been analyzed by comparing the yearly rainfall deficiency with the mean yearly rainfall. Yearly drought analysis has also been performed by three climatic indexes. The climatic indexes are De Mortone Aridity Index, IdM; Seleaninov Hydrothermic Index, IhS; and Donciu Climate Index, ICD. With the help of annual rainfall assurance (A\%) yearly drought analysis has been performed by the climatic indexes. Monthly drought analysis has been done with the rainfall data, considering average rainfall and minimum rainfall for a month. In this study 17 meteorological stations have been chosen for analysis. Distribution of rainfall, annual variation of rainfall, yearly drought and percentage of drought affected areas has been presented with the help of different figures and tables. Monthly drought analysis shows that generally the month of January, February, March, November and December are drought affected. The month of April faces drought almost every year. May and October face drought occasionally. The months June, July, August and September experience heavy rainfall.
\end{abstract}

Keywords: Drought, IdM, IhS, IcD and Annual rainfall assurance (A\%).

\section{Introduction}

Drought is a normal, recurring feature of climate; it occurs virtually in all climatic regimens. It is a temporary aberration, in contrast to aridity, which is a permanent feature of regional climate. Drought should be considered relative to some long-term average condition of balance between precipitation and evapotranspiration in a particular area, a condition often perceived as "Normal". Common to all types of drought is the fact that they originate from a deficiency of precipitation those result in water shortage for some activity or for some group. It is also commonly recognized that other meteorological elements, such as temperature, wind, and relative humidity, may aggravate the severity and impacts of drought in some instances.

Bangladesh is an agricultural country. The irrigation system is not much developed. There are heavy rainfalls in rainy season in our country but the rainfall occurrence in other season is very low. Thus the rainfall distribution throughout the region and year is non uniform. This non uniform rainfall very often causes droughts in every year. Drought causes severe stresses to crops as well as animals. Therefore the analysis of drought and to find out the prevention measure for it is very important in our country. Drought is a "Creeping Phenomenon". The effect of drought accumulates slowly over a considerable period of time and may linger for years after the termination of the event. Drought impacts spread over a larger geographical area than are damages that result from other natural hazards. Like floods, Bangladesh is vulnerable to recurrent droughts. After 1971 Bangladesh has experienced droughts of major magnitude in 1972, 1973, 1975, 1979, 1980, 1983, 1985, 1992, 1994 and 1995. Although droughts are not always continuous in any area, they do occur sometimes in the rainfall zones of the county. As listed above, Bangladesh experienced consecutive droughts during 1972-1973, 19791980 and 1994-1995.

Two critical dry periods are distinguished. Rabi and pre-Kharif drought occur due to: the cumulative effect of dry days; higher temperatures during pre- Kharif and low soil moisture availability.

This drought affects all the Rabi crops, such as Boro and Aus rice, wheat, pulses and potatoes especially where irrigation possibilities are limited. It also affects sugarcane production. Kharif droughts in the period June/July to October, is created by sub-humid and dry 
conditions in the highland and medium highland areas of the country. Shortage of rainfall affects the critical reproductive stages of transplanted Aman crops in December, reducing its yield, particularly in those areas with low soil moisture holding capacity.

The eastern part is prone to drought mainly because of rainfall variability in the pre-monsoon and the post-monsoon periods. Inadequate premonsoon showers, a delay in the onset of the rainy season or early departure of the monsoon may create drought conditions in Bangladesh and adversely affect crop output. Since it puts severe strain on the land potential, increased soil erosion, decline in soil organic contents and overexploitation of sparse vegetation. An analysis of the relative effects of flood and drought on rice production between 1969-70 and 1983-84 shows that drought is more devastating than floods to aggregate production. The following are the main objectives of this study:

- To measure the characteristics of rainfall in the study area.

- To analyze the drought for individual year on the basis of rainfall.

- To analyze yearly drought using climatic indexes.

- To analyze the drought for individual months by rainfall.

\section{Different Methods of Drought Analysis}

The term drought has different significance in different parts of the world. Different countries have different ways to analysis drought.

In order to analyze drought meteorological drought analysis method has been adopted. In this method both yearly and monthly drought analyses have been performed by using the rainfall data. Yearly drought analysis has also performed by three climatic indexes. The climatic indexes are De Mortone Aridity Index, IdM; Seleaninov Hydrothermic Index, IhS; and
Donciu Climate Index, IcD. With the help of annual rainfall assurance (A\%) yearly drought analysis has been performed by the climatic indexes.

\subsection{Yearly Meteorological Drought Analysis by Rainfall Deficiency}

The analysis of yearly drought has been done by calculating the yearly average rainfall from 1971 to 2004. From appendix, $50 \%$ and $25 \%$ of normal rainfall has been calculated. The 25\% deficiency of rainfall has been calculated by deducting the $25 \%$ of average rainfall from average rainfall. Then comparing with year the drought analysis has been done according to the Indian Meteorological Department (IMD). If the annual rainfall is greater then the value of $25 \%$ deficiency then it is normal rainfall. If the annual rainfall is between $25 \%$ and $50 \%$ deficiency then it is moderate drought. If the annual rainfall is less then the value of $50 \%$ deficiency then it is severe drought. Further, a year is considered as a drought year during which the area affected by moderate or severe drought either individually or collectively is more than $20 \%$ of the total area of the country.

\subsection{Yearly Drought Analysis by the Climatic Indexes}

The characterization of the drought periods by climatic indexes has been done. The climatic indexes are De Mortone Aridity Index, IdM; Seleaninov Hydrothermic Index, IhS; and Donciu Climate Index, IcD. The correlation established between the assured rainfall (A\%) for years and climatic indexes provide the polynomial expression, statistically very significant. It has quantified very significant correlation between annual rainfall assurance (A\%) and climatic indexes using logarithmic expression which is shown in Table 1.

Table 1: Correlation between Annual Rainfall Assurance (A\%) and the Climatic Indexes

\begin{tabular}{|l|c|c|}
\hline \multicolumn{1}{|c|}{ Climatic index } & Symbol & Mathematical function \\
\hline Mortone aridity index & IdM & IdM $=-7.3566 \ln \mathrm{A}+58.037$ \\
\hline Seleaninov hydrotheremic index & His & IhS $=-0.4006 \ln \mathrm{A}+3.1001$ \\
\hline Donciu climate index & IcD & IcD $=-24.269 \ln \mathrm{A}+191.17$ \\
\hline
\end{tabular}


Table 2: The Value of Interpretation Limits for Climatic Indexes

\begin{tabular}{|l|c|c|c|}
\hline \multirow{2}{*}{\multicolumn{1}{|c|}{ Characterization }} & \multicolumn{3}{|c|}{ Climatic index } \\
\cline { 2 - 4 } & IdM & Ihs & IcD \\
\hline Excessive rainy & $>40$ & $>2.0$ & $>110$ \\
\hline Very rainy & $33-40$ & $1.6-2$ & $100-110$ \\
\hline Rainy & $29-33$ & $1.4-1.6$ & $95-100$ \\
\hline Medium & $25-29$ & $1.3-1.4$ & $80-95$ \\
\hline Droughty & $24-25$ & $1.1-1.3$ & $70-80$ \\
\hline Very droughty & $23-24$ & $1.0-1.1$ & $65-70$ \\
\hline Excessive droughty & $<23$ & $<1.0$ & $<65$ \\
\hline
\end{tabular}

a period of years by Bangladesh Meteorological

The data registered in the meteorological stations were used for the calculation of the climatic indexes. The annual rainfall assurance (A\%) has been calculated from appendix. The average rainfall of all years has been determined. Percentage of rainfall for every years of average rainfall has been determined. Deducting percentage value from 150 the annual rainfall assurance (A\%) has been found. By putting the value of $\mathrm{A}$ in each climatic index equation the value of each climatic index has been determined. By comparing the value of climatic indexes with the Table 2 the yearly drought analysis has been performed.

\section{Data Collection}

There are many meteorological stations in Bangladesh. These stations record various climatologically data such as temperature, pressure, wind, rainfall, relative humidity over

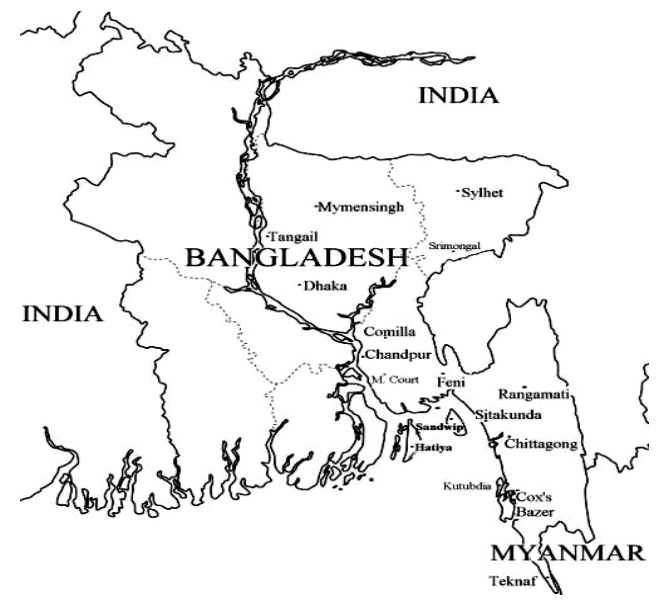

Fig. 1: Map Showing Meteorological Stations of Eastern Part of Bangladesh
Department (BMD). The daily rainfall data of 17 stations of the eastern part of Bangladesh for 34 years (1971-2004) were collected from the Bangladesh Meteorological Department (BMD).

\section{Study Area}

The project area is eastern part of Bangladesh that is selected for drought analysis. 17 meteorological stations were selected for analysis which is shown in Fig. 1.

\section{Results and Discussion}

Drought has been analyzed for the period of 1971 to 2004 in eastern part of Bangladesh. 17 major meteorological stations were considered for the analysis of drought. The analysis was performed in yearly and monthly basis.

From the analysis it is seen that the studied area experience a lot of rain during the months of May to September, the rainfall is moderate in the months of April and October, the rainfall is low in the months of January, February, March, November and December. Monthly rainfall pattern for Dhaka has been shown in Fig. 2.

From the trend line of the yearly variation of rainfall it is seen that the total rainfall is increasing in the study area of Mymensingh, Chittagong, Cox's Bazar, Kutubdia, Sitakunda, Kumilla, Maizdi Court, Hatiya, Rangamati, Teknaf and Srimongal; decreasing in the study area of Dhaka, Chandpur, Sylhet and Tangail, In Feni and Sandwip there is almost no variation in rainfall. The trend line for the annual variation of rainfall at Dhaka is shown in Fig. 3. 


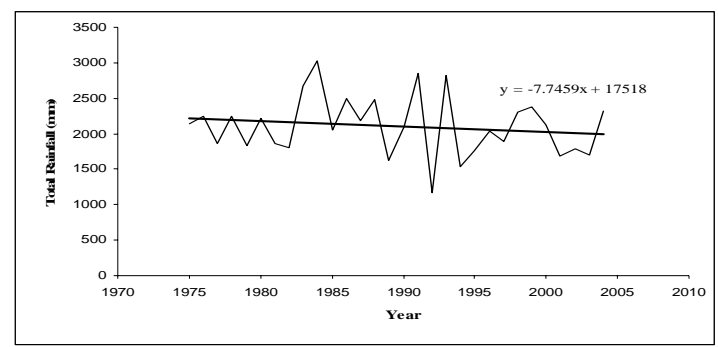

Fig. 3: Annual Variation of Rainfall of Dhaka (1971-2004)

Yearly drought analysis by rainfall deficiency for every station was calculated which is shown in Table 3.

Table 3: Yearly Drought Analysis by Rainfall Deficiency

\begin{tabular}{|c|c|c|c|}
\hline $\begin{array}{l}\text { Sl. } \\
\text { No }\end{array}$ & Station & $\begin{array}{c}\text { Moderat } \\
\text { Drought }\end{array}$ & $\begin{array}{c}\text { Severe } \\
\text { Drought } \\
\end{array}$ \\
\hline 1 & Chandpur & $\begin{array}{l}\text { 1973, 1989, } \\
1992,1994\end{array}$ & \begin{tabular}{|l|}
1974,1975, \\
1977 \\
\end{tabular} \\
\hline 2 & Chittagong & 1972, 1976 & 2001 \\
\hline 3 & Comilla & $\begin{array}{l}1972,1979, \\
1989,1992, \\
1994\end{array}$ & 1971 \\
\hline 4 & Cox’s Bazar & 1972, 1976 & $\begin{array}{l}1979,1980, \\
1985\end{array}$ \\
\hline 5 & Dhaka & 1992,1994 & -- \\
\hline 6 & Feni & $\begin{array}{l}1980,1983, \\
1992,1994 \\
\end{array}$ & 1979 \\
\hline 7 & Hatiya & 1973,1994 & 1990,1993 \\
\hline 8 & Kutubdia & -- & $\begin{array}{l}\text { 1977,1979, } \\
1980\end{array}$ \\
\hline 9 & Maizdi Court & 1971,1992 & \begin{tabular}{|l|}
1972,1973, \\
1975,1978 \\
\end{tabular} \\
\hline 10 & Mymensingh & $\begin{array}{l}1971,1985, \\
1991,1994 \\
\end{array}$ & 1973,1979 \\
\hline 11 & Rangamati & $\begin{array}{l}\text { 1972,1982, } \\
1992,1994\end{array}$ & -- \\
\hline 12 & Sandwip & 1995 & 2003 \\
\hline 13 & Sitakunda & -- & 1979,1980 \\
\hline 14 & Srimangal & $\begin{array}{l}1972,1973, \\
1974,1975, \\
1979\end{array}$ & $\begin{array}{l}1971,1980, \\
1985\end{array}$ \\
\hline 15 & Sylhet & -- & 1971 \\
\hline 16 & Tangail & -- & -- \\
\hline 17 & Teknaf & 1983 & 1979,1980 \\
\hline
\end{tabular}

Yearly drought has also been analyzed by the climatic indexes. Three climatic indexes such as: de Mortone aridity index, (IbM); Seleaninoy hydrothermic index, (IhS); and Donciu climatic index, (IcD) were used. The results are shown in Table 4,5 and 6.

Table 4: Yearly Drought Analysis of Different Stations by De Mortone Aridity Index

\begin{tabular}{|r|l|l|l|l|}
\hline $\begin{array}{r}\text { Sl. } \\
\text { No }\end{array}$ & \multicolumn{1}{|c|}{ Station } & Drought & $\begin{array}{c}\text { Very } \\
\text { Drought }\end{array}$ & $\begin{array}{l}\text { Excessive } \\
\text { Drought }\end{array}$ \\
\hline 1 & Chandpur & & 1975 & $\begin{array}{l}1972,1973 \\
1978\end{array}$ \\
\hline 2 & Chittagong & 1972 & & 2001 \\
\hline 3 & Comilla & & 1971 & \\
\hline 4 & Cox's Bazar & & & $\begin{array}{l}1979,1980, \\
1985\end{array}$ \\
\hline 5 & Dhaka & 1992 & & \\
\hline 6 & Feni & $\begin{array}{l}1980, \\
1983,\end{array}$ & & 1979 \\
\hline 7 & Hatiya & 1990, & & 1993 \\
\hline 8 & Kutubdia & & 1977 & 1979,1980 \\
\hline 9 & $\begin{array}{l}\text { Maizdi } \\
\text { Court }\end{array}$ & 1973 & & 1974,1975, \\
\hline 10 & Mymensingh & & & 1977 \\
\hline 11 & Rangamati & 1972, & & 1979,1979 \\
\hline 12 & Sandwip & & & 2003 \\
\hline 13 & Sitakunda & & & 1979,1980 \\
\hline 14 & Srimangal & 1974, & 1980, & 1971 \\
\hline 15 & Sylhet & & & 1971 \\
\hline 16 & Tangail & --- & & \\
\hline 17 & Teknaf & & & 1979,1980 \\
\hline
\end{tabular}

Table 5: Yearly Drought Analyses of Different Stations by Seleaninov Hydrothermic Index

\begin{tabular}{|c|c|l|c|c|}
\hline $\begin{array}{c}\text { Sl. } \\
\text { No }\end{array}$ & Station & Drought & $\begin{array}{c}\text { Very } \\
\text { Drought }\end{array}$ & $\begin{array}{c}\text { Excessiv } \\
\text { e } \\
\text { Drought }\end{array}$ \\
\hline 1 & Chandpur & $\begin{array}{l}1973, \\
1974, \\
1975, \\
1977\end{array}$ & --- & --- \\
\hline 2 & Chittagong & $\begin{array}{l}1972, \\
2001\end{array}$ & --- & --- \\
\hline
\end{tabular}




\begin{tabular}{|c|c|c|c|c|}
\hline $\begin{array}{l}\text { Sl. } \\
\text { No }\end{array}$ & Station & Drought & $\begin{array}{c}\text { Very } \\
\text { Drought }\end{array}$ & $\begin{array}{c}\text { Excessiv } \\
\mathrm{e} \\
\text { Drought }\end{array}$ \\
\hline 3 & Comilla & 1971, & --- & --- \\
\hline 4 & Cox’s Bazar & $\begin{array}{l}1979, \\
1985 \\
\end{array}$ & --- & --- \\
\hline 5 & Dhaka & 1992 & --- & --- \\
\hline 6 & Feni & $\begin{array}{l}1979, \\
1980, \\
1983, \\
1992\end{array}$ & --- & --- \\
\hline 7 & Hatiya & $\begin{array}{l}1990, \\
1993, \\
1994 \\
\end{array}$ & --- & --- \\
\hline 8 & Kutubdia & $\begin{array}{l}1977, \\
1979, \\
1980\end{array}$ & --- & --- \\
\hline 9 & $\begin{array}{l}\text { Maizdi } \\
\text { Court }\end{array}$ & $\begin{array}{l}1972, \\
1973, \\
1975, \\
1978\end{array}$ & --- & --- \\
\hline 10 & Mymensingh & $\begin{array}{l}1973, \\
1979\end{array}$ & --- & --- \\
\hline 11 & Rangamati & $\begin{array}{l}1972, \\
1982 \\
\end{array}$ & --- & --- \\
\hline 12 & Sandwip & 2003 & --- & --- \\
\hline 13 & Sitakunda & $\begin{array}{l}1979, \\
1980 \\
\end{array}$ & --- & --- \\
\hline 14 & Srimangal & $\begin{array}{l}1971, \\
1974, \\
1975, \\
1980, \\
1985\end{array}$ & --- & --- \\
\hline 15 & Sylhet & 1971 & & \\
\hline 16 & Tangail & --- & & \\
\hline 17 & Teknaf & $\begin{array}{l}1979, \\
1980\end{array}$ & & \\
\hline
\end{tabular}

Table 6: Yearly Drought Analyses of Different Stations by Donciu Climate Index

\begin{tabular}{|c|l|l|c|c|}
\hline $\begin{array}{c}\text { Sl. } \\
\text { No }\end{array}$ & Station & Drought & $\begin{array}{c}\text { Very } \\
\text { Drought }\end{array}$ & $\begin{array}{c}\text { Excessive } \\
\text { Drought }\end{array}$ \\
\hline 1 & Chandpur & $\begin{array}{l}1974, \\
1975, \\
1977\end{array}$ & --- & --- \\
\hline 2 & Chittagong & 2001 & --- & --- \\
\hline 3 & Comilla & 1971 & --- & --- \\
\hline 4 & Cox's Bazar & $\begin{array}{l}1979, \\
1980, \\
1985\end{array}$ & --- & --- \\
\hline
\end{tabular}

\begin{tabular}{|c|l|l|c|c|}
\hline $\begin{array}{c}\text { Sl. } \\
\text { No }\end{array}$ & \multicolumn{1}{|c|}{ Station } & Drought & $\begin{array}{c}\text { Very } \\
\text { Drought }\end{array}$ & $\begin{array}{c}\text { Excessive } \\
\text { Drought }\end{array}$ \\
\hline 5 & Dhaka & --- & --- & --- \\
\hline 6 & Feni & $\begin{array}{l}1979, \\
1980\end{array}$ & --- & --- \\
\hline 7 & Hatiya & $\begin{array}{l}1990, \\
1993, \\
1994\end{array}$ & --- & --- \\
\hline 8 & Kutubdia & $\begin{array}{l}1977, \\
1979, \\
1980\end{array}$ & --- & --- \\
\hline 9 & Maizdi & $\begin{array}{l}1972, \\
1973, \\
1975, \\
1978\end{array}$ & --- & --- \\
\hline 10 & Myurt & $\begin{array}{l}1973, \\
1979\end{array}$ & --- & --- \\
\hline 11 & Rangamati & --- & --- & --- \\
\hline 12 & Sandwip & 2003 & --- & --- \\
\hline 13 & Sitakunda & $\begin{array}{l}1979, \\
1980\end{array}$ & --- & --- \\
\hline 14 & Srimangal & $\begin{array}{l}1971, \\
1980, \\
1985\end{array}$ & --- & --- \\
\hline 15 & Sylhet & 1971 & --- & --- \\
\hline 16 & Tangail & --- & --- & --- \\
\hline 17 & Teknaf & $\begin{array}{l}1979, \\
1980\end{array}$ & --- & --- \\
\hline
\end{tabular}

It has been found that in Dhaka moderate drought occurred in 1992 and 1994. Other years had normal rainfall. In 1971, 1972, 1977, 979, 1981, 1982, 1989, 1994, 1995, 1997, 2001, 2002 and 2003 were medium. Other years were rainy. It has been found that in Dhaka from November to March it is in drought condition. Sometimes April and October were effected by drought. Other months were rainy.

In Mymensingh severe drought occurred in 1973 and 1979. Moderate drought occurred in 1971, 1985, 1991 and 1994. Other years had normal rainfall. From November to March it is in drought condition in Mymensingh. Sometimes April, September and October were effected by drought. Other months were rainy.

It was observed that in Chittagong excessive drought occurred in 2001 and drought occurred in 1972. The rainfall was medium in 1975, 1976, 1977, 1978, 1981, 1984, 1987, 1989, 1991, 1992 , 1994 and 1995. Other years were rainy. In 
Chittagong from November to March it is in drought condition. Sometimes April and October were effected by drought. Other months were rainy.

The years 1979, 1980 and 1985 were severe drought affected in Cox's Bazar. Moderate drought occurred in 1972 and 1976. Other years had normal rainfall. It has been found that in Cox's Bazar from November to March it is in drought condition. Sometimes April and October were effected by drought. Other months were rainy.

In Kutubdia excessive drought occurred in 1979 and 1980. The year 1977 was very droughty. The rainfall was medium in 1989, 2001, 2002, 2003 and 2004. The years 1990, 1996 and 1998 were very rainy. Other years were rainy. The month November to April it is in drought condition in Kutubdia. Sometimes May and October were effected by drought. Other months were rainy.

Drought occurred in 1979 and 1980 in Sitakunda. The rainfall was medium in 1981 and 1992. The years 1983, 1984, 1990 and 1998 were excessive rainy. The years 1978, 1982, 1987, 1988, 1993, 1994, 2000 and 2004 were very rainy. Other years were rainy. From table 4.9.6 it has been found that in Sitakunda from November to March it is in drought condition. Sometimes April and October were effected by drought. Other months were rainy.

In Comilla severe drought occurred in 1971. Moderate drought occurred in 1972, 1979, 1989, 1992 and 1994. Other years had normal rainfall. From Table 4.9.7 it has been found that in Comilla from November to February it is in drought condition. Sometimes March and September were effected by drought. Other months were rainy.

In Chandpur severe drought occurred in 1974, 1975 and 1977. Moderate drought occurred in 1973, 1979, 1992 and 1994. Other years had normal rainfall. The month October to February it is in drought condition in Chandpur. Sometimes March and September were effected by drought. Other months were rainy.

In Maizdi Court excessive drought occurred in 1972, 1973 and 1978. The year 1975 was very droughty. Other years were rainy. In month November to March it is in drought condition in Maizdi Court. Sometimes April, May and
October were effected by drought. Other months were rainy.

It has been found that in Feni excessive drought occurred in 1979. The years 1980, 1983 and 1992 were droughty. The rainfall was medium in 1978, 1985, 1986, 1994, 1996, 1997, 2001, 2002 and 2003. Other years were rainy. In Feni November to March it is in drought condition. Sometimes April and October were effected by drought. Other months were rainy.

In Hatiya excessive drought occurred in 1993. The years 1990 and 1994 were droughty. The rainfall was medium in 1971, 1973, 1976, 1982, 1983, 1985, 1985, 1986, 1987, 1989 and 1992. Other years were rainy. The month November to March it is in drought condition in Hatiya. Sometimes April, May and October were effected by drought. Other months were rainy.

It has been found that in Sandwip severe drought occurred in 2003. Moderate drought occurred in 1995. Other years had normal rainfall. In Sandwip November to March it is in drought condition. Sometimes April and October were effected by drought. Other months were rainy. Moderate drought occurred in 1972, 1982, 1992 and 1994 in Rangamati. Other years had normal rainfall. It has been found that in Rangamati November to March it is in drought condition. Sometimes April and October were effected by drought. Other months were rainy.

In Teknaf severe drought occurred in 1979 and 1980. Moderate drought occurred in 1983. Other years had normal rainfall. It has been found that in Teknaf November to April it is in drought condition. Sometimes April, May and October were effected by drought. Other months were rainy.

It has been found that in Sylhet the year 1971 was very droughty. The rainfall was medium in 1972, 1977, 1980, 1986, 1987, 1992, 1994, 1995, 1997, 1999, 2001, 2002 and 2003. Other years were rainy. It has been found that in Sylhet November to March it is in drought condition. Sometimes April and October were effected by drought. Other months were rainy.

In Srimongal severe drought occurred in 1971, 1980 and 1985. Moderate drought occurred in 1972, 1973, 1974, 1975 and 1979. Other years had normal rainfall. It has been found that in Srimongal November to March it is in drought 
condition. Sometimes April and October were effected by drought. Other months were rainy. In has been found that in Tangail there is no drought affected years. All years had normal rainfall. It has been found that in Tangail November to March it is in drought condition. Sometimes April and October were effected by drought. Other months were rainy.

It has been found that in 1972 and 1973 almost $24 \%$ of the stations were affected by moderate drought. Almost $40 \%$ of the stations were moderate drought affected in 1992 and 1994. It has been seen that in 1979 almost 36\% of total stations were severely drought affected.

So the years 1972, 1973, 1979, 1992 and 1994 were drought affected year.

It has been seen that correlation between annual rainfall assurance (A\%) and climatic index is better for IdM and IhS.

From November to March it is in drought condition. Sometimes April and October were effected by drought. Other months were rainy.

It has been seen that Excessive drought and very drought occurred in Chittagong, Cox's Bazar, Kutubdia, Sitakunda, Chandpur, Maizdi Court, Teknaf and Srimongal. Drought occurred in Mymensingh, Comilla, Feni and Rangamati.

From yearly meteorological drought analysis by rainfall deficiency it is seen that severe drought occurred in 1971, 1973, 1974, 1979, 1980, 1985 and 2003. Moderate drought occurred in 1972, 1976, 1981, 1991, 1992, 1994 and 1995. Severe drought occurred Chittagong, Cox's Bazar, Kutubdia, Sitakunda, Maizdi Court Teknaf and Srimongal. Moderate drought occurred in Mymensingh, Comilla, Chandpur, Feni and Rangamati. Hatiya and Sandwip was sometimes severe drought affected and sometimes moderate drought affected. Sometimes excessive drought occurred in Cox's Bazar, Kutubdia, Sitakunda and Maizdi Court.

\section{Conclusions}

The following conclusions can be drawn from this study:

- It is found that from November to March all the study area experiences a drought. Sometimes in the months of April, September and October drought occurred.
- Severe drought occurred in 1971, 1973, 1974, 1979, 1980, 1985 and 2003 in the study area of Chittagong, Cox's Bazar, Kutubdia, Sitakunda, Maizdi Court, Teknaf and Srimongal.

- Moderate drought occurred in the years of 1972, 1976, 1981, 1991, 1992, 1994 and 1995 in the study area of Mymensingh, Comilla, Chandpur, Feni and Rangamati.

- Sometimes excessive drought occurred in Cox’s Bazar, Kutubdia, Sitakunda and Maizdi Court.

- Though the study does not fully state the drought condition it gives a primary idea about the drought condition of the study area to face the drought adaptability and remedial measure for the alleviation of the drought for the reason concerned.

\section{Acknowledgement}

The first author gratefully acknowledges to Bangladesh Meteorological Department (BMD).

\section{References}

[1] Subramanya, K., 2001. Engineering Hydrology, $2^{\text {nd }}$ Edition, Tata McGraw-Hill Book Co. New Delhi.

[2] Raghunath, H. M., 1985. Hydrology, New Age International (PVT) Limited, India.

[3] Garg, S. K., 1976. Irrigation Engineering \& Hydraulic Structure, Khanna Publishers, Delhi.

[4] Chow, V .T, 1964. Hand Book of Applied Hydrology, McGraw-Hill Book Co. New York, USA.

[5] Chandra, D. G., 1989. Fundamentals of Agronomy, Oxford \& IBH Publishers Co. PVT. Limited, New Delhi.

[6] Sen, S. K., Hossain, M. E., 2001. Analysis of Drought in Barind Tract, Unpublished B. Sc. Engineering Thesis, Rajshahi University of Engineering \& Technology.

[7] Hossain, M. S., Arifujjaman, M., 2002. Analysis of Drought in North Western Part of Bangladesh, Unpublished B. Sc. Engineering Thesis, Rajshahi University of Engineering \& Technology.

[8] National Drought Mitigation Centre (2006), What is drought,

[9] http://www.drought.unl.edu/what

[10] is/concept.htm

[11] American Meteorological society, 1997. ASM Policy Statement of Meteorological Drought 
[12] Faculty of Environmental Protection, Agricultural Research Institute, University of Oradea, Romania, Drought Analysis by the Climatic Indexes,

[13] http://www.wg.crop.icidonline.org

[14] Institute of Food and Agricultural Sciences, University of Florida, 1998. The Disaster Handbook, Chapter 16: Extreme Heat and Drought, National Edition.

[15] Chaudt, Q. Z., History’s Worth Drought

[16] Conditions Prevailed, www.meteorologicaldroughtinpakistan.htm

[17] Beran, M. A., Rodier, J. A., Hydrological Aspects of Drought, A contribution to the International Hydrological Program, Unesco.
[18] Bangladesh Meteorological Department, Rainfall Data for the period 1971 to 2004 at 17 stations in Bangladesh, Dhaka

\section{Appendix}

For the meteorological station Dhaka:

Total Rainfall for 33 years $=68,935 \mathrm{~mm}$.

Average Rainfall per year $=68,935 \div 33$

$$
=2088.9393 \mathrm{~mm} \text {. }
$$

In 1971, Annual Rainfall $=1,922 \mathrm{~mm}$.

Percentage value $=1,922 \div 2088.9393 \times 100$

$$
=92 \%
$$

Annual Rainfall Assurance (A \%) $=150-92$

$$
=57 \%
$$

